\title{
Intelligent System Based Solar Biomass Hybrid Dryer for Perishable Crops and Leafy Vegetables
}

\author{
B.A. Anand ${ }^{1 *}$, P. Manjunath Babu ${ }^{2}$ and B.A. Sunil Raj ${ }^{3}$ \\ ${ }^{I}$ Department of Agricultural Engineering, UAS, GKVK, Bangalore, Karnataka, India \\ ${ }^{2}$ Department of Electrical and Electronics Engg, BMSIT, Bangalore, Karnataka, India \\ ${ }^{3}$ Department of Mechanical Engineering, ACSCE, Bangalore, Karnataka, India \\ *Corresponding author
}

\section{A B S T R A C T}

\begin{tabular}{|l|}
\hline K e y w o r d s \\
$\begin{array}{l}\text { Dryer, Leafy Vegetables, } \\
\text { Perishable Crops, } \\
\text { Thermal efficiency }\end{array}$ \\
\hline Article Info \\
\hline $\begin{array}{l}\text { Accepted: } \\
\text { 12 September } 2018 \\
\text { Available Online: } \\
10 \text { October } 2018\end{array}$ \\
\hline
\end{tabular}

Minimising Post Harvest Loses for the perishable crops are the major area of demand driven technology intervention have been sorted in the present era in the country. India as an tropical country, which has large scope for solar drying, and simultaneously it is an agrarian country with huge agricultural wastes generated after harvesting every seasons produces large scale Biomasses. Solar Energy and Biomass together are utilized to produce required amount of heat to remove moisture in the perishable crops inside a drying chamber with the simulated controlled atmosphere is the area of research in this paper. This dryer uses intelligent system which is based on microcontroller, which monitors the temperature and humidity inside the dryer chamber, this controlled atmosphere helps us to maintain desired temperature as well as humidity in the drying chamber. This unit is tested for onions, garlic, and leafy vegetables in this research.

\section{Introduction}

Food scientists have found that by reducing the moisture content of food to between 10 and $20 \%$, bacteria, yeast, mould and enzymes are prevented from spoiling it. The flavour and most of the nutritional value is preserved and concentrated. Drying and preservation of agricultural products have been one of the oldest uses of solar energy. The traditional method, still widely used throughout the world, is open sun drying where diverse crops, such as fruits, vegetables, cereals, grains, tobacco, etc. are spread on the ground and turned regularly until sufficiently dried so that they can be stored safely. However, there exist many problems associated with open sun drying. It has been seen that open sun drying has the following disadvantages. It requires both large amount of space and long drying time.

The disadvantages of open sun drying need an appropriate technology that can help in improving the quality of the dried products and in reducing the wastage. This led to the application of various types of drying devices like solar dryer, electric dryers, wood fuel driers and oil-burned driers. However, the high cost of oil and electricity and their scarcity in the rural areas of most third world countries have made some of these driers very 
unattractive. Therefore interest has been focused mainly on the development of solar driers.

Solar biomass dryers are usually classified according to the mode of air flow into natural convection and forced convection dryers. Natural convection dryers do not require a fan to pump the air through the dryer. The low air flow rate and the long drying time, however, result in low drying capacity. One basic disadvantage of forced convection dryers lies in their requirement of electrical power to run the fan. Since the rural or remote areas of many developing countries are not connected, the use of these dryers is limited to electrified urban areas. Drying is the oldest preservation technique of agricultural products and it is an energy intensive process. High prices and shortages of fossil fuels have increased the emphasis on using alternative renewable energy resources. Drying of agricultural products using renewable energy such as solar energy is environmental friendly and has less environmental impact (Ajayi et al., 2009; Brenidorfer et al., 1995; El-Sebaii and Shalaby, 2012; Fadhel et al., 2005; Gutti Babagana et al., 2012; Bala et al., 2003; Wang et al., 2012; Zhonghua et al., 2012; Jiang et al., 2012).

Different types of solar dryers have been designed, developed and tested in the different regions of the tropics and subtropics. The major two categories of the dryers are natural convection solar dryers and forced convection solar dryers.

In the natural convection solar dryers, the airflow is established by buoyancy induced airflow while in forced convection solar dryers the airflow is provided by using fan operated either by electricity/solar module or fossil fuel or biomass (Kaewkiew et al., 2012; Afriyie et al., 2009; Sharma et al., 2009; Sodha et al., 1985).
Solar Biomass technology is a technology that is rapidly gaining acceptance as an energy saving measure in agriculture application. It is preferred to other alternative sources of energy such as wind and shale, because it is abundant, inexhaustible, and non-polluting. Solar air heaters are simple devices to heat air by utilizing solar energy and it is employed in many applications requiring low to moderate temperature below $70^{\circ} \mathrm{C}$, such as crop drying and space heating (Thoruwa et al., 2000; Jyothi Singh, 2015).

\section{Materials and Methods}

Solar biomass drying may be classified into one. In solar biomass dryers, the air heater contains the grains and solar energy which passes through a transparent cover and is absorbed by the grains. Essentially, the heat required for drying is provided by radiation to the upper layers and subsequent conduction into the grain bed.

However, in indirect dryers, solar energy is collected in a separate solar collector (air heater) and the heated air then passes through the grain bed, while in the mixed mode type of dryer, the heated air from a separate solar collector is passed through a grain bed, and at the same time, the drying cabinet absorbs solar energy directly through the transparent walls or the roof. With this the biomass gas is also utilised for dying out process. The objective of this study is to design a mixed-mode solar biomass dryer in which the grains are dried simultaneously by both direct radiation through the transparent walls and roof of the cabinet.

The materials used for the construction of the mixed-mode solar dryer are cheap and easily obtainable in the local market. Figure 1 shows the main components of the dryer, consisting of the solar collector (air heater), the drying cabinet and drying trays. 


\section{Heat chamber}

The heat absorber (inner box) of the solar air heater was constructed using well painted black. The solar collector assembly consists of air flow channel enclosed by transparent cover (glazing).

An absorber mesh screen midway between the glass cover and the absorber back plate provides effective air heating because solar radiation that passes through the transparent cover is then absorbed by both the mesh and back-plate.

\section{The drying cabinet}

The drying cabinet together with the structural frame of the dryer was built from wellseasoned woods which could withstand termite and atmospheric attacks. An outlet vent was provided toward the upper end at the back of the cabinet to facilitate and control the convection flow of air through the dryer.

Access door to the drying chamber was also provided at the back of the cabinet. The roof and the two opposite side walls of the cabinet are covered with transparent glass sheets of 4 $\mathrm{mm}$ thick, which provided additional heating.

\section{Drying trays}

The drying trays are contained inside the drying chamber and were constructed from a double layer of fine chicken wire mesh with a fairly open structure to allow drying air to pass through the food items.

\section{Boiler}

Biomass is burnt in boiler and the gas flew away and gets accumulated over the Heating chamber and tries to heat up the top surface with the help of hot air gases which makes the system dry out at a faster rate

\section{Energy analysis of the solar air heater latent storage collector}

The energy analysis presented in this section is mainly based on the first law of thermodynamics.

The theoretical model employed for the study of the SAHLSC consists of using a thermal energy balance during both the charging and discharging phases:

$Q_{A}=Q_{u}+Q_{s t}+Q_{\text {los }}(1)$

Where $\mathrm{Q}_{\mathrm{A}}, \mathrm{Qu}, \mathrm{Qst}$, and $\mathrm{Q}_{\text {los }}$ are the absorbed, useful, stored, and lost energy, respectively.

Based on Duffie and Beckman, the useful heat gain from the collector is:

$Q_{u}=m C_{p}\left(T_{\text {out }}-T_{\text {in }}\right)$

Where

$m=\rho V_{a v} S$

$\mathrm{V}_{\mathrm{av}}$ and $\mathrm{S}$ are average air velocity and cross sectional area of the duct at the inlet of the solar air heater, respectively. The radiation absorbed flux of the absorber packed-bed is defined as:

$Q_{A}=A(\alpha \tau) I_{T}$

where $(\alpha \tau)$ is the effective product transmittance absorptance that is equal with the optical efficiency $\left(\eta_{\mathrm{o}}\right)$.

The stored heat flux during the charging and discharging phases is given by:

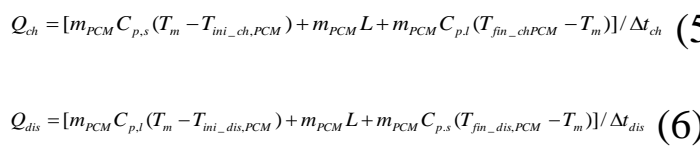


The lost heat flux is given by relation, Ulos is the collector overall heat loss coefficient. The thermal energy lost from the collector to the surroundings by conduction, convection, and infrared radiation. Ulos is equal to the sum of energy loss through the top (Ut), bottom (Ub), and edges (Ue) of the collectors given below:

$$
\begin{aligned}
& Q_{\text {los }}=U_{\text {los }} A_{c}\left(T_{p}-T_{a}\right) \\
& U_{\text {los }}=U_{t}+U_{b}+U_{e}(8)
\end{aligned}
$$

The top loss coefficient from the collector to the ambient is:

$$
U_{t}=\left(1 /\left(h_{c, p_{-} g}+h_{r, p_{-} g}\right)+1 /\left(h_{w}+h_{r, g_{-} a}\right)\right)^{-1}
$$

The flow is laminar during the charging phase; and the appropriate correlation is given by Churchill:

$$
\begin{aligned}
& N u_{c h}=2+(0.589 R a)^{1 / 4} /\left(1+\left((0.469)^{9 / 16}\right)^{1 / 4}\right. \\
& {\left[P_{r} \geq 0.7\right]} \\
& {\left[R_{a} \leq 10^{11}\right]}
\end{aligned}
$$

Then the flow is turbulent during the discharging phase; the appropriate correlation is given by Whitaker :

$\mathrm{Nu}_{\text {dis }}=2+\left(0.4 \mathrm{R}_{\mathrm{e}}^{1 / 2}+0.06 \mathrm{R}_{\mathrm{e}}{ }^{2 / 3}\right) \operatorname{Pr}^{0.4}\left(\mu / \mu_{\mathrm{s}}\right)^{1 / 4}$ (11)

$[0.71 \leq \operatorname{Pr} \leq 380]$

$N u_{d i s}=2+\left(0.4 R_{e}^{1 / 2}+0.06 R_{e}^{2 / 3}\right) \operatorname{Pr}^{0.4}\left(\mu / \mu_{s}\right)^{1 / 4}$

$$
\begin{aligned}
& {\left[3.5 \leq R_{e} \leq 7.610^{4}\right]} \\
& {\left[1 \leq\left(\mu / \mu_{s}\right) \leq 3.2\right]} \\
& h_{c p_{-} g}=N u(\lambda / t) \\
& h_{c p_{-} g}=\left(\sigma\left(T_{p}{ }^{2}+T_{g}{ }^{2}\right)\left(T_{p}+T_{g}\right)\right) /\left(\left(1 / \varepsilon_{g}\right)-1\right)
\end{aligned}
$$

The heat transfer coefficient due to convection at the top of cover due to wind is given by Hottel and Woertz:

$h_{w}=5.67+3.86 V_{\infty}$

$h_{r, g_{-} a}=\varepsilon_{g} \sigma\left(T^{2}+T_{s k y}^{2}\right)\left(T_{g}+T_{s k y}\right)$

The appropriate approximation to sky temperature is given by swinbak:

$$
T_{s k y}=0.0052 T_{a}^{1.5}
$$

In addition the energy loss through the bottom $(\mathrm{Ub})$ and the edges (Ue) equation as follows:

$U_{b}=\lambda_{i} / \delta_{b}$

$U_{e}=\left(L_{1}+L_{2}+L_{3}\right)$

$U_{e}=\left(L_{1}+L_{2}\right) L_{3} \lambda_{i} /\left(L_{1} L_{2} \delta_{e}\right)$

\section{Thermal efficiency}

The thermal efficiency based on the first law of thermodynamics is defined as the ratio between the useful energy and the solar radiation incident on the collector.

$$
\eta=Q_{u} A_{c} I_{T}
$$

The daily average thermal efficiency of the SAHLSC is the ratio of the desired energy output during the discharging process to the total energy input during the charging process. (Sukhante and Nayak, 2014) (Bharathesh et al., 2015)

$$
\eta=\int_{d i s} Q_{d i s} / \int_{c h} A_{c} I_{T}
$$




\section{Results and Discussion}

Intelligent Solar Bio Mass Hybrid Dryer are used to modify the temperature and humidity inside the chamber using microcontroller based intelligent system with heater and humidity control system as successfully removed moisture from the vegetables as desired has been illustrated in the table 1 .

The results obtained demonstrate the efficiency of the system to remove the moisture content from the vegetables with minimum power consumption.

Fig.1 Intelligent system based hybrid solar biomass dryer 3D view
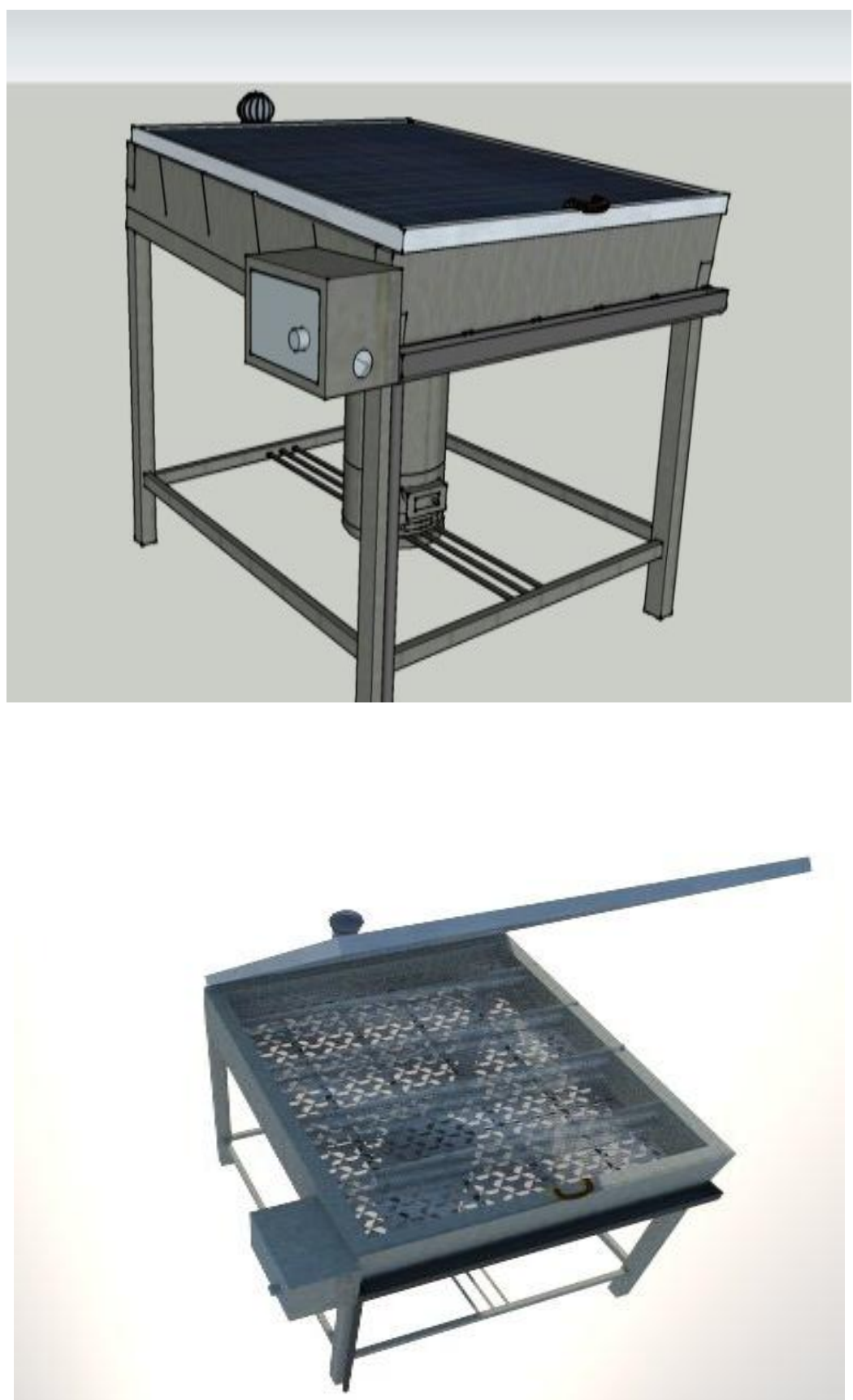
Table.1 Solar drying data with respective to moisture content and time

\begin{tabular}{|c|c|c|c|c|}
\hline \multirow{2}{*}{ Product } & \multicolumn{2}{|c|}{$\begin{array}{c}\text { Moisture Content } \\
\text { Initial (\%) }\end{array}$} & $\begin{array}{c}\text { Maximum } \\
\text { Fllowalble }\end{array}$ & Drying Time (h) \\
\hline Onion Rings & 82 & 18 & 55 & $36-40$ \\
\hline Green Chillies & 76 & 10 & $55-60$ & $48-60$ \\
\hline Grapes & 83 & 15 & $65-70$ & $40-45$ \\
\hline Apple & 80 & 12 & $65-70$ & $28-30$ \\
\hline Cabbage & 80 & 20 & 55 & $38-42$ \\
\hline Spinach Leaves & 75 & 6 & 60 & $36-40$ \\
\hline Curry Leaves & 65 & 4 & 60 & $36-40$ \\
\hline
\end{tabular}

In conclusion, the need for the construction of intelligent system based solar-biomass dryer arose as an alternative for ordinary sun drying techniques as been demonstrated in this research. Intelligent system based dryer are most effective in the present scenario since temperature and humidity of drying chamber can be varied as desired with application of microcontroller based controller. The results obtained have demonstrated the system capabilities and efficiency.

\section{References}

Afriyie, J.K., M.A.A. Nazha, H. Rajakaruna, F.K. Forson 2009. Experimental investigations of a chimney dependent solar crop dryer, Renewable Energy 34, 217- 222.

Ajayi, C., Sunil, K.S., and Deepak, D. 2009. "Design of Solar Dryer with Turbo ventilator and Fireplace". International Solar Food Processing Conference 2009.

Bala, B.K., M.R.A. Mondol, B.K. Biswas, B.L. Das Chowdury, S. Janjai (2003): Solar drying of pineapple using solar tunnel drier, Renewable Energy 28, 183-190.

Bharathesh B.H., Gokul $\mathrm{K}$ and $\mathrm{M}$. Eswarmoorthy 'Experimental evaluation of solar heater with thermal storage for drying Applications' a technical reported submitted to International Conference on Advances in Energy Research 2015.

Brenidorfer B, Kennedy L, Bateman C O (1995). Solar dryer; their role in postharvest processing, Commonwealth Secretariat Marlborough house, London, Swly 5hx.

El-Sebaii, A.A., and S.M. Shalaby (2012): Solar drying of agricultural products: A review, Renewable and Sustainable Energy Reviews 16, 37- 43.

Fadhel, S. Kooli, A. Farhat, A. Bellghith, (2005). Study of the solar drying of grapes by three different processes, Desalination 185, 535-541.

Gutti Babagana, Kiman Silas and Mustafa B. G. (2012). Design and Construction of Forced/Natural Convection Solar Vegetable Dryer with Heat Storage, ARPN Journal of Engineering and Applied Sciences, VOL. 7, NO. 10.

Jiang, Y., Xu, P., Mujumdar, A.S., Qiu, S., Jiang, Z. A Numerical study on the convective heat transfer characteristics of pulsed impingement drying (2012) Drying Technology, 30 (10), pp. 10561061.

Jyothi Singh, "Review Paper of study of Solar Dryer" 2015, Journal of Mechanical and Mechanics Engineering, Vol 1 issue 1 page 14-24 
Kaewkiew, J., S. Nabnean; S. Janjai (2012): Experimental investigation of the performance of a large-scale greenhouse type solar dryer for drying chilli in Thailand. Procedia Engineering 32, 433 $-439$.

Sharma, A., Chen, C. R., Vu Lan, N., 2009. Solar- energy drying systems: A review. Renewable and Sustainable Energy Reviews, Vol.13, pp. 1185-1210.

Sodha, M.S., Dang, A., Bansal, P.K., Sharma, S.B., 1985. An analytical and experimental study of open sun drying and a cabinet type drier. Energy Conversion \& Management, Vol. 25(3), pp. 263-271.

Sukhante, S P, and J K Nayak, Solar Energy, Principles of Thermal Collection and Storage, McGraw Hill Education Inc 2014
Thoruwa, T.F.N., Johnstone, M.C., Grant, A.D., Smith, J.E., 2000. Novel, low cost $\mathrm{CaCl} 2$ based desiccants for solar crop drying applications. Renewable Energy, Vol.19, pp. 513-520.

Wang, Y., Zhang, M., Mujumdar, A.S., Mothibe, K.J., Roknul Azam, S.M. Effect of blanching on microwave freeze drying of stem lettuce cubes in a circular conduit drying chamber, (2012) Journal of Food Engineering, 113 (2), pp. 177-185.

Zhonghua Dr., W., Long, W., Zhanyong, L., Mujumdar, A.S. Atomization and Drying Characteristics of Sewage Sludge inside a Helmholtz Pulse Combustor (2012) Drying Technology, 30 (10), pp. 1105-1112.

\section{How to cite this article:}

Anand, B.A., P. Manjunath Babu and Sunil Raj, B.A. 2018. Intelligent System Based Solar Biomass Hybrid Dryer for Perishable Crops and Leafy Vegetables. Int.J.Curr.Microbiol.App.Sci. 7(10): 1701-1707. doi: https://doi.org/10.20546/ijcmas.2018.710.195 